\title{
The effect of long-term administration of opioids on the ultrastructure of the white rat's tricuspid valve heart valve
}

\author{
L. Mateshuk-Vatseba, R. Symivska
}

Department of General Anatomy, Danylo Halytskyi Lviv National Medical University, Pekarska Street, 69, 79-010 Lviv, Ukraine
Corresponding author. Email: roxolana.kohut@ gmail.com

Paper received 24.02.20; Accepted for publication 16.03.20.

https://doi.org/10.31174/SEND-NT2020-233VIII28-12

\begin{abstract}
The first signs of disruption of the ultramicroscopic structure of the tricuspid valve of the white rat heart were detected after 2 weeks of experimental exposure to nalbuphin, which was manifested by changes in the thickness of the endothelial cell in its various parts, a decrease in the number of microvilli on the surface of endothelial cells and swollen cells. In the course of the experiment lasting 6 weeks, destructive changes increased, which led to the disorganization of the structure of the tricuspid heart valve of the white rat. Changes in the shape and size of endothelial cells, their loss of contact with the destroyed and homogenized basement membrane, the destruction of collagen and elastic fibers. The connective tissue exposed as a result of endothelial damage is infiltrated by blood lipids, indicating the onset of fatty degeneration.
\end{abstract}

Keywords: heart, tricuspid valve, opioid, nalbuphine, experiment, ultrastructural.

Introduction. Anesthesia is one of the most important tasks in the work of a doctor, because pain is the main cause of suffering and treatment of patients for medical help [1]. According to WHO, about $90 \%$ of all diseases are associated with pain, and patients with chronic pain are five times more likely to seek medical treatment, compared with the underlying disease [2]. The history of medicine has long been associated with the use of opioids as the main means of analgesia [14]. There is an increasing trend in the world of opioid use, which contributes to the improvement of somatic, visceral and neuropathic pain [4]. However, it should be noted that doctors are reluctant to prescribe opioids, except in cases of acute pain (surgery, trauma, childbirth) or cancer patients, fearing side effects, leaving a large number of patients without real help, condemning them to suffering [3]. Opioids improve the effectiveness of analgesia and the quality of life of patients [5]. Not infrequently, the opioid arsenal and physicians' knowledge was limited to the use of morphine, which has long been the 'gold standard' [8]. However, the biggest problem with the use of morphine is the lack of a 'boundary effect' and linear dose-response [9]. Nowadays, the opioid agonist-antagonist-nalbuphine is widely popular $[6,7]$. The analgesic effect of nalbuphine is not inferior to morphine and does not require special control, unlike the latter $[10,11]$. Unfortunately, there are no data on the influence of the opioid mean of nalbuphine on cardiac function, namely ultramicroscopic changes of the valve apparatus of the heart under the influence of nalbuphine, some studies are observational and the available conclusions are insufficiently substantiated [12,13].

Aim. To establish the features of the ultrastructural organization of the tricuspid white rat heart valve with longterm administration of opioid in the experiment.

Матеріали і методи The study was performed on 25 mature white male rats aged 3.0 months and body weight 160-180 g. The experimental group consisted of 20 animals to which Nalbuphine hydrochloride (Rusanpharma LTD., India) was injected intramuscularly every day during 6 weeks. Administration of nalbufin was conducted intramuscularly as follows: I week $-8 \mathrm{mg} / \mathrm{kg}$, II week $15 \mathrm{mg} / \mathrm{kg}$, III week - $20 \mathrm{mg} / \mathrm{kg}$, IV week $-25 \mathrm{mg} / \mathrm{kg}$, V week - $30 \mathrm{mg} / \mathrm{kg}$, VI week - $35 \mathrm{mg} / \mathrm{kg}$ [15].The control group consisted of 5 white rats to which saline solution (Indar, Kyiv, Ukraine) was injected. The animals were removed from the experiment in the second, fourth and sixth weeks.
All animals were kept in a vivarium within the Danylo Halytsky Lviv National Medical University. The experiments were conducted in compliance with the provisions of the "Guide for the care and use of laboratory animals, 8th edition, 2018." Euthanasia was performed by way of overdosing intraperitoneal anesthesia using Thiopental sodium (Kyivmedpreparat, Kyiv, Ukraine). The research material was presented by ultrathin sections of the white rat heart valve.

Electron microscopic study was conducted in compliance with generally adopted methods. Electron microscopic examination of the valve of white rats was performed on a TEM-100 transmission electron microscope. They were photographed using a SONY-19 digital camera.

Results and Discussion. The first signs of disruption of the ultramicroscopic structure of the white rat's tricuspid valve of the heart were detected after 2 weeks of experimental exposure to nalbuphine. There is a change in the thickness of the endothelial cell in its various parts: the nuclear zone containing the endothelial nucleus is thinned, the number of openings (fenesters) increases in the peripheral zone. The nucleus retains its elongated (oval) shape. The number of microvilli on the surface of the endothelial cell decreases. The endothelial cells are still bound by tight contact contacts. The endothelium is located on a relatively thick basement membrane, which has a thin-fibril structure (image 1).

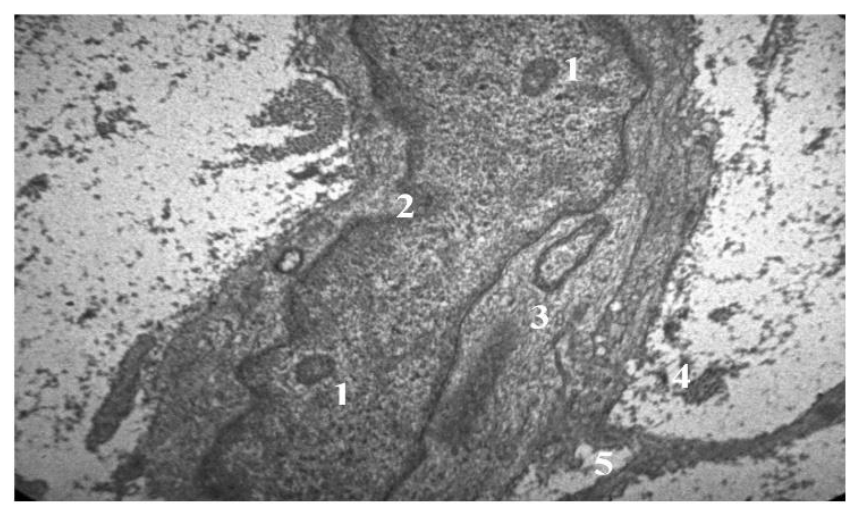

Image. 1 Ultrathin section of endothelial cells at the base of the white rat tricuspid valve with 2-week nalbuphine exposure in the experiment. Electronic micrograph. ST: 8000.

1-oval endothelial cell nucleus; 2- thinning of the endothelial cell nuclear envelope; 3-zone organelles; 4- reducing the number of microvilli on the surface of the endothelial cell; 5- endothelial cell connection with the basement membrane. 
Dense unformed fibrous connective tissue is represented by thick tufts of collagen fibers, which are oriented in different directions. Collagen fibers are swollen, their divergence is lost, and homogenization of elastic fibers is indicated, which indicates the onset of surface layers loosening (image. 2). Fibroblasts retain the appearance of large cells with processes. Smooth myocytes have a fusiform shape and the presence of seedlings on the surface. They are enveloped by a thin basement membrane to which collagen fibrils are attached.

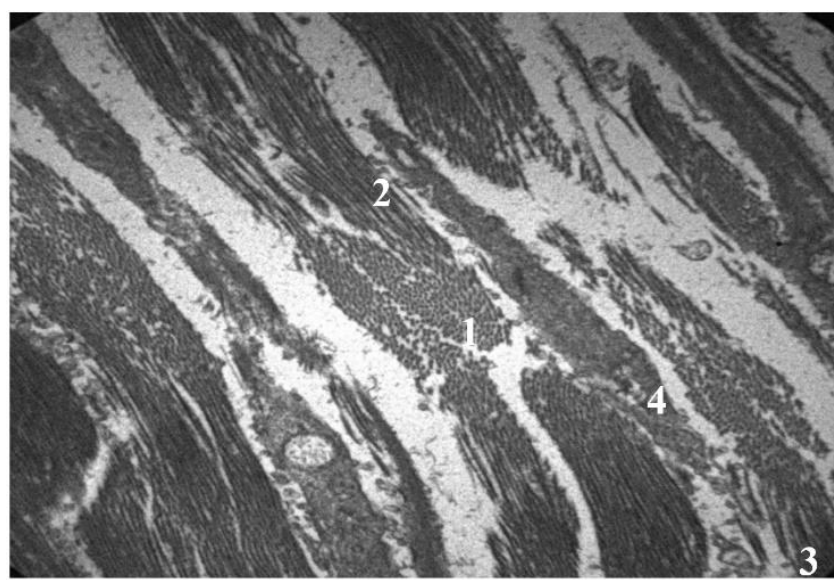

Image 2 The connective tissue basis of the white rat tricuspid valve of the heart in 2-week exposure to nalbuphine in the experiment. Electronic micrograph. ST: 4000.

1- cross-sectioned tufts of collagen fibers; 2- longitudinal direction of collagen fibers; 3- swelling and homogenization of surface layers of collagen fibers; 4- smooth myocyte.

In the long-term exposure to narcotic analgesics of nalbuphine, there were destructive changes in the ultramicroscopic structure of the bicuspid white rat heart valve. There was a decrease in size and change in the shape of the endothelial cells, thinning of the peripheral sections of endothelial cells, partial or complete destruction of their plasmolema, appearance in the cytoplasm of vacuoles with myelin-like structures, deformation of the nucleus with thickening or destruction of nucleolema, as well as the destruction or compaction and homogenization of the basement membrane with which the endothelial cells lost contact. The number of microvillis on the surface of the endothelial cell decreases, or the tight closing contacts between the endothelial cells are broken or destroyed (image 3).

In places of desquamation of the endothelium, layers of smooth myocytes with signs of increased synthetic activity were found, in the cytoplasm of which there were tubules of the endoplasmic reticulum with numerous ribosomes, large mitochondria and polysomes. The cytoplasm of other smooth myocytes contained single organelles, vacuoles with fine material, and membrane structures that formed myelin-like formations. The endomysium formed between muscle cells, elastic and thin collagen fibers is destroyed. There is a stratification of elastic fibers, microfibrils swell and lose contact with glycoproteins.

The connective tissue, exposed as a result of endothelial damage, is infiltrated by blood lipids. In response, lipophages accumulate in the lesion sites, and fat deposits accumulate in the intercellular space. The surface layers are loosened: swelling, homogenization of collagen fibers and their merging into small foci, often fragmentation of necrotized collagen beams, the latter becoming homogeneous and electron-dense (image 4). The fibroblasts are not densely arranged, chaotic, and have an elongated shape with two or three processes. The cytoplasm of cells contained one large drop of fat, which displaced the nucleus to the periphery directly to the cell membrane. This indicated the beginning of the degeneration of the loose fibrous connective tissue into adipose tissue.

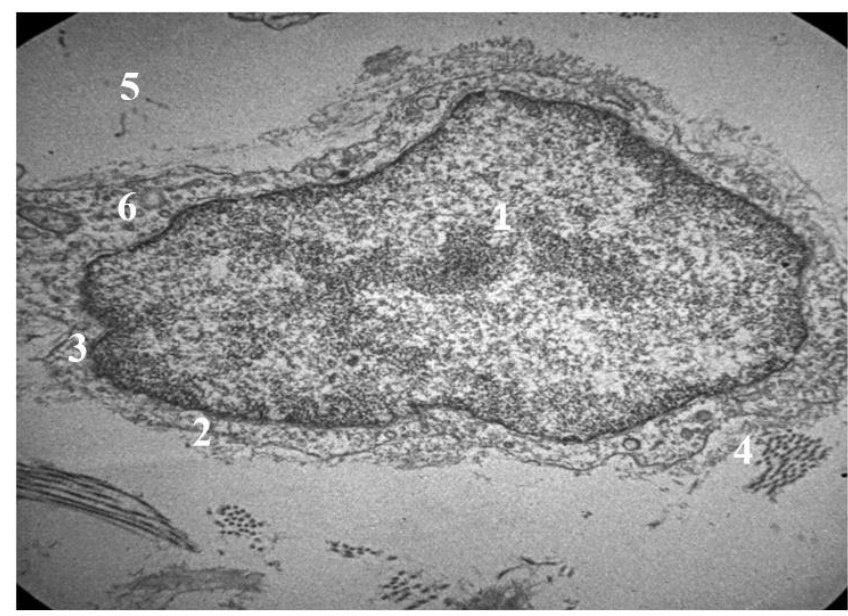

Image 3. Ultrathin section of endothelial cells at the base of the tricuspid white rat heart valve with long-term exposure to nalbuphine in the experiment. Electronic micrograph. ST: 8000. 1- deformed nucleus with destroyed nucleolem; 2- change in the shape of the endothelial cell nuclear envelope; 3-thinning of the cytoplasm of endothelial cells; 4- reducing the number of microvillis on the surface of the endothelial cell; 5- homogenization of the basement membrane; 6- inclusion of vacuoles with myelin-like structures.

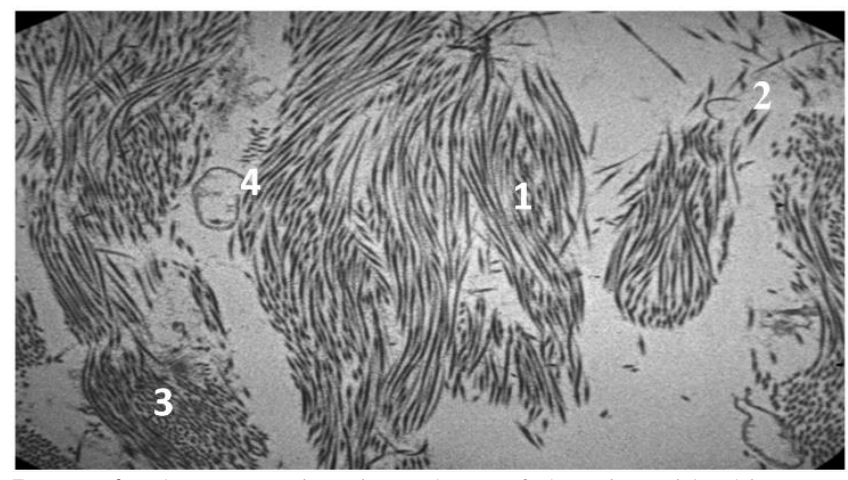

Image 4. The connective tissue base of the tricuspid white rat heart valve with 6-week nalbuphine exposure in the experiment. Electronic micrograph. ST: 4000.

1- loosening of the surface layers of collagen fibers; 2- fragmentation of necrotized collagen beams; 3 - stratification of elastic fibers: swelling of myofibrils and loss of their connection with glycoproteins; 4- a splash of fat;

Conclusions. Analyzing the results of the experimental study of the ultramicroscopic structure of the tricuspid white rat heart valve with long-term opioid exposure, we can talk about the destructive changes of the main components, which become noticeable from the 2 nd week of the experiment and lead to the gradual degeneration of the valve apparatus into the fatty tissue closer to the 6th week of the experiment. 


\section{REFERENCES}

1. Ducoffe AR, Baehr A, Peña JC, Rider BB, Yang S, Hu DJ., Adverse Drug Event Prevention: 2014 Action Plan Conference, Am J Med Qual., 2015. pii: 1062860615588105. [Epub ahead of print] . PMID:26024666

2. Chou R, Turner JA, Devine EB, et al. The effectiveness and risks of long-term opioid therapy for chronic pain: a systematic review for a National Institutes of Health Pathways to Prevention Workshop. Ann Intern Med 2015; 162:276.

3. Karim Nagi and Graciela Piñeyro. Regulation of opioid receptor signalling: Implications for the development of analgesic tolerance. Mol Brain. 2011 Jun 13;4:25. doi: 10.1186/17566606-4-25.

4. Turk DC, Wilson HD, Cahana A. Treatment of chronic noncancer pain. Lancet 2011; 377:2226

5. Von Korff M, Kolodny A, Deyo RA, Chou R. Long-term opioid therapy reconsidered. Ann Intern Med 2011; 155:325.

6. Bekesevych A, Mateshuk-Vatseba L. Peculiarities of cerebellar cortex ultrastructure under the influence jf opioid in experiment. Science end Education a New Dimension. Natural and Technical Sciences. 2016;4(91):36-40.

7. Pidvalna U. Ye. Structural organization of organs and systems under the influence of opioids / U. Ye. Pidvalna // Experimental and clinical physiology and biochemistry. - 2014 - №1 (65). - pp. 71-78.

8. Order of the Ministry of Health of Ukraine dated 14.01.2009 №13 «On approval of the form guide on the use of medicines in anesthesiology and intensive care»
9. Ismailova, US, Altaeva, AJ, Bekisheva, AN, Alsherieva, UA. Addiction, morphine and morphism. Gazette of the Kazakh National Medical University. 2013,3-2 :

10. Kobelyatsky, Yu. Modern aspects of the use of the mixed opioid receptor agonist of nalbuphine in clinical practice / Yu. - Dnepropetrovsk. - 2012. - №1. - pp. 61-64.

11. Yeh Y.C., Lin T.F., Chang H.C. et al. Combination of lowdose nalbuphine and morphine in patient-controlled analgesia decreases incidence of opioid-related side effects // J. Formos. Med. Assoc. - 2009. - Vol. 108 (7). - P. 548-553.

12. Yeh Y.C., Lin T.F., Lin F.S. et al. Combination of opioid agonist and agonist-antagonist: patient-controlled analgesia requirement and adverse events among different-ratio morphine and nalbuphine admixtures for postoperative pain // Br. J. Anaesth. - 2008. - Vol. 101 (4). - P. 542-548.

13. Voronkov M. Administration of nalbuphine to heroin addicts. Feasibility and short-term effects / M. Voronkov, D. Ocheret, S. Bondarenko // Heroin Addict Relat Clin Probl. 2008. — №10 (1). - P.19-24.

14. Classification of chronic pain. Descriptions of chronic pain syndromes and definitions of pain terms. Prepared by the International Association for the Study of Pain, Subcommittee on Taxonomy. Pain Suppl. 1986; 3:S1-226.

15. Pat. №76564 U Ukraine, MPK A 61 K 31/00 Method of modeling of physical opioid dependence in rats / Applicants: Onysko R.M., Paltov Ye.V., Fik V.B., Vilkhova I.V., Kryvko Yu.Ya ., Yakymiv N.Ya., Fitcalo O.S.; patent holder: Danylo Halytsky Lviv National Medical University. - №201207124; stated. 12.06.2012; has published 10/01/2013, Byul. №1. 